\title{
PENGEMBANGAN BOOKLET KEANEKARAGAMAN PTERIDOPHYTA DI KAWASAN SUBAN AIR PANAS UNTUK SISWA SMA
}

\author{
Rosma Fitriasih ${ }^{1}$, Irwandi Ansori ${ }^{1}$, Kasrina ${ }^{1}$ \\ ${ }^{1}$ Program Studi Pendidikan Biologi, Fakultas Keguruan dan Ilmu Pendidikan, Universitas Bengkulu \\ Email : rosma.fitriasih@gmail.com
}

\begin{abstract}
Abstrak
Penelitian ini bertujuan untuk mendata keanekaragaman spesies tumbuhan Pteridophyta yang tumbuh di kawasan wisata Suban Air Panas Kabupaten Rejang Lebong dan membuat booklet tumbuhan paku-pakuan yang valid dan efektif sehingga dapat dijadikan sebagai bahan ajar Biologi bagi siswa kelas X SMA Negeri 1 Rejang Lebong pada materi pelajaran tumbuhan (Plantae) subbab Pteridophyta. Jenis penelitian ini adalah Penelitian Dan Pengembangan (Research and Development) dengan model pengembangan 4D (four- $D$ ) yang terdiri dari empat tahap yaitu Define (pendefinisian), Design (perencanaan), Devolope (pengembangan), dan Disseminate (penyebaran). Adapun tahapan yang digunakan yaitu hanya pada batas tahap Devolope (pengembangan). Instrumen pengumpulan data yang digunakan adalah pedoman wawancara, lembar angket kebutuhan siswa, lembar observasi lapangan, lembar karakteristik morfologi, lembar validasi booklet dan angket respon siswa. Berdasarkan penelitian yang dilakukan, ditemukan 14 spesies tumbuhan paku. 7 famili Polypodiaceae, 1 famili Dryopteridaceae, 1 famili Adiantaceae, 1 family Selaginellaceae, 1 famili Equisetaceae, 1 family Pteridaceae dan 1 famili Marattiaceae. Booklet yang telah dikembangkan dinyatakan valid dengan nilai akhir $92 \%$ dan dengan kriteria sangat baik. Data angket respon siswa menunjukkan bahwa booklet efektif dijadikan bahan ajar dengan presentase $83 \%$ dengan kategori sangat baik. Sehingga dapat disimpulkan bahwa booklet yang dikembangkan dapat dijadikan bahan ajar dan efektif sebagai alternative sumber belajar biologi kelas X SMA N 1 Rejang Lebong pada materi ajar tumbuhan (Plantae) subbab Pteridophyta.
\end{abstract}

Kata Kunci : Booklet, Pteridophyta, Bahan Ajar.

\begin{abstract}
This research aims to record the diversity of Pteridophyta plant species that grow in the tourist area of Suban Rejang Lebong Regency and make the valid and effective fern plant booklets, so it can be used as a teaching materials for the students class X SMA Negeri 1 Rejang Lebong on plant learning materials (Plantae) in chapter Pteridophyta. The type of this research is research and development with four-D development model, there are Define (definition), Design (planning), Devolope (development), and Disseminate (spread). The stages used in this research is only the development stage. The data collection instrument used are, interview guidelines, the students need questionnaire, observation sheet, morphological characteristics sheets, booklet validation sheet, and student response questionnaires. Based on research conducted, the researcher found 14 species of fern plants. They are, 7 Polypodiaceae families, 1 Dryopteridaceae family, 1 Adiantaceae family, 1 Selaginellaceae family, 1 Equisetaceae family, 1 Pteridaceaedan family, 1 Marattiaceae family. The developed booklet is valid with a final score $92 \%$ and very good criteria. The data of the students response questionnaire show that booklet used as a teaching material is effective because got $83 \%$ percentage with very good category. It can be concluded that the booklet developed can be used as teaching materials and effective as an alternative source of biology learning for class X SMA N 1 Rejang Lebong on the material of plants (Plantae) chapter Pteridophyta.
\end{abstract}

Keywords: Booklet, Pteridophyta, Teaching Materials. 


\section{PENDAHULUAN}

Kurikulum 2013 mengembangkan dua proses pembelajaran yaitu proses pembelajaran langsung (direct teaching) dan proses pembelajaran tidak langsung (indirect teaching). Proses pembelajaran langsung adalah proses pembelajaran yang mengembangkan pengetahuan, kemampuan berpikir dan keterampilan psikomotorik peserta didik melalui interaksi langsung dengan sumber belajar yang dirancang. Ada berbagai macam sumber belajar yang dapat digunakan guru dan siswa untuk meningkatkan pemahaman konsep sains bagi siswa. Sumber belajar itu ada 2 yaitu: 1) Sumber belajar yang dirancang (Learning resources by design), yaitu sumber belajar yang sengaja dirancang atau dikembangkan sebagai komponen sistem intruksional untuk memberikan fasilitas belajar yang terarah dan bersifat formal. 2) Sumber belajar yang dimanfaatkan (Learning resources by utililization), yaitu sumber belajar yang tidak didesain khusus untuk keperluan pembelajaran dan keberadaannya dapat ditemukan, diterapkan dan dimanfaatkan untuk keperluan pembelajaran (Prastowo, 2011).

Guru bertugas untuk mengelola pembelajaran agar terjadi interaksi antara bahan ajar dengan siswa sehingga proses belajar dapat berlangsung dengan baik. Menurut Suyitno (2011) bahan ajar merupakan seperangkat materi yang disusun secara sistematis baik tertulis maupun tidak tertulis, sehingga tercipta lingkungan/suasana yang memungkinkan siswa untuk belajar. Bahan ajar ini merupakan informasi, alat dan teks yang diperlukan guru/instruktur untuk perencanaan dan penelaahan implementasi pembelajaran yang disusun secara sistematis.
Bahan ajar memiliki beberapa jenis. Adapun jenis-jenis bahan ajar sebagai berikut: (1) bahan ajar pandang (visual) terdiri atas bahan cetak (printed) seperti antara lain: handout, buku, modul, lembar kerja siswa (LKS), brosur, leaflet, wallchart, foto/gambar, dan non cetak (non printed), seperti model/maket, (2) Bahan Ajar dengar (audio) seperti kaset, radio, piringan hitam, dan compact disk audio, (3) Bahan ajar pandang dengar (audio visual) seperti video compact disk, film, dan (4) bahan ajar multimedia interaktif (interactive teaching material) seperti CAI (Computer Assisted Instruction), compact disk (CD) multimedia pembelajaran interaktif, dan bahan ajar berbasis web (web based learning materials) (Majid, 2009).

$$
\text { Pengelolaan materi dalam }
$$

pembelajaran merupakan salah satu aspek penting dalam mewujudkan efektivitas pembelajaran. Pengelolaan materi pelajaran mencakup pemilihan, pengembangan, pengorganisasian, penyajian, serta penentuan strategi dan prosedur pembelajaran. Pembelajaran yang berlangsung di sekolah biasanya menggunakan buku teks. Menurut Suyitno (2011), buku teks merupakan sumber informasi yang disusun dengan struktur dan urutan berdasarkan bidang ilmu tertentu. Sedangkan menurut Suryaman (2006) dalam Imtihana, dkk (2014) buku teks adalah sumber informasi yang disusun secara sistematis, sistemik, dan objektif dengan struktur dan urutan yang disesuaikan dengan ciri atau karaketristik masing-masing bidang keilmuan. Apabila siswa membuka sebuah buku teks pelajaran, yang ditemukan adalah halaman yang penuh dengan deretan tulisan kecil-kecil, terkadang dilengkapi dengan gambar ataupun diagram.

Sekarang sudah banyak dikembangkan bahan ajar untuk peserta didik selain buku yang disediakan oleh 
pemerintah. Salah satunya booklet, Booklet merupakan perpaduan antara buku dan Leaflet. Booklet sebagai suatu sumber belajar dapat digunakan untuk menarik minat dan perhatian siswa karena bentuknya yang sederhana dan banyaknya warna serta gambar yang ditampilkan. Selain itu, booklet dapat dibaca dimanapun dan kapanpun sehingga dapat membantu meningkatkan pemahaman siswa (Pralisaputri dkk, 2015). Berdasarkan hasil wawancara yang telah dilakukan bahwa guru biologi kelas $X$ SMA Negeri 1 Rejang Lebong, terdapat kesulitan dalam melakukan inovasi dan pengembangan terhadap bahan ajar. Hal ini dikarenakan kurangnya keterampilan dan kemampuan dalam mengolah bahan ajar menjadi sumber belajar yang menarik dan layak digunakan siswa. Saat ini guru biologi masih berpedoman dengan menggunakan buku dan LKS yang disediakan oleh pemerintah, padahal guru dapat membuat bahan ajar dengan melihat potensi lingkungan yang ada di sekitar lingkungan peserta didik yang kemudian dapat dikembangkan menjadi salah satu bahan ajar.

Menurut pusat data dan informasi Kementrian Lingkungan Hidup dan Kehutanan tahun 2016, Indonesia merupakan Negara dengan tingkat keanekaragaman hayati tinggi ke 3 di dunia. Salah satu contohnya yaitu tumbuhan paku-pakuan (Pteridophyta). Tumbuhan paku banyak tersebar dari daerah tropis maupun daerah sub tropis, terutama tempat-tempat yang lembab (Soesilo, 1986).

Tumbuhan paku atau Pteridophyta merupakan suatu divisi dari kingdom Plantae. Divisi ini warganya sudah jelas mempunyai kormus, artinya tubuhnya dengan nyata dapat dibedakan dalam tiga bagian pokoknya, yaitu akar, batang, dan daun. Namun demikian, pada tumbuhan paku belum dihasilkan biji. Alat perkembangbiakan tumbuhan paku yang utama adalah spora (Tjitrosoepomo, 2001).

Provinsi Bengkulu memilliki jumlah curah hujan tahunan yang relatif tinggi, bervariasi antara 2000 - $6000 \mathrm{~mm}$ pertahun dan jumlah hari hujan bervariasi antara 100 - 250 hari pertahun. Suhu udara rata-rata $25,60 \mathrm{C}$, suhu minimum berkisar antara 21,4 ㅇ $\mathrm{C}$ sampai $22,50 \mathrm{C}$ dan suhu maksimum rata-rata antara 31,4 ㅇ C sampai 32,5 ㅇ C. Kelembaban udara rata-rata diatas $50 \%$ dengan lama penyinaran matahari rata-rata 6 Jam per hari dan penguapan rata-rata $4 \mathrm{Mm}$ perhari. Keadaan angin di Provinsi Bengkulu dominan dari arah Barat dan Selatan. Kecepatan rata-rata $8 \mathrm{~km} / \mathrm{jam}$, dengan kecepatan maksimum rata-rata 34 $\mathrm{km} / \mathrm{jam}$ dan kecepatan maksimum absolut pernah mencapai $81 \mathrm{~km} / \mathrm{jam}$. Dilihat dari keadaan geografis Kabupaten Rejang Lebong. Wilayah dengan ketinggian tempat $>500$ - $750 \mathrm{mdpl}$, meliputi areal seluas 228.881 ha yang menyebar disebagian besar Kabupaten Lebong dan Rejang Lebong (RPJMD, 2014).

Obyek Wisata Suban Air panas merupakan lokasi wisata yang terletak +6 $\mathrm{km}$ dari Kota Curup. Di lokasi ini juga terdapat air terjun yang indah dengan ketinggian $+90 \mathrm{~m}$ dengan air yang jernih dan dingin. Selain itu terdapat pula batu yang dianggap keramat yang diberi nama Batu Menangis oleh masyarakat setempat. Obyek wisata alam Suban Air Panas ini merupakan wisata unggulan di Provinsi Bengkulu pada umumnya dan Kabupaten Rejang Lebong (Izmuka, 2015). Maka dapat diduga bahwa kawasan ini memiliki keanekaragaman spesies tumbuhan Pteridophyta yang sangat tinggi. Tingginya keanekaragaman tumbuhan Pteridophyta diharapkan dapat menjadi bahan ajar nyata siswa.

Penelitian ini bertujuan untuk 1) mengetahui jenis-jenis tumbuhan paku 
yang terdapat di kawasan Wisata Suban Air Panas Curup Kabupaten Rejang Lebong; 2) menghasilkan dan mengetahui kelayakan booklet berdasarkan identifikasi tumbuhan paku (Pteridophyta) yang terdapat dikawasan Suban Air Panas untuk siswa Kelas X SMA Negeri 1 Rejang Lebong Materi Tumbuhan.

\section{METODE PENELITIAN}

Jenis penelitian yang digunakan adalah dengan metode Penelitian dan Pengembangan (Research and Development). Metode penelitian Research and Development adalah metode penelitian yang digunakan untuk menghasilkan produk tertentu, dan menguji keefektifan produk tersebut (Sugiyono, 2008). Menurut Arifin (2011), Penelitian dan pengembangan adalah serangkaian proses atau langkah-langkah dalam rangka mengembangkan suatu produk baru atau menyempurnakan produk yang telah ada agar dapat dipertanggung jawabkan.

Metode yang digunakan adalah metode deskriptif kualitatif, Penyusunan dan pengembangan booklet ini mengikuti model pengembangan 4-D (four-D) oleh Thiagarajan (1974) dalam Arifin (2011) dengan tahapan define, design, develop dan disseminate. Penelitian ini dilakukan pada bulan Maret 2017 sampai Mei 2017 di kawasan Obyek Wisata Suban Air Panas Kabupaten Rejang Lebong dan Implementasi Booklet dilakukan di kelas $X$ IPA 5 SMA Negeri 1 Rejang Lebong pada materi tumbuhan. Untuk pengambilan sampel dilakukan dengan cara membagi kawasan Obyek Wisata Suban Air Panas menjadi 4 bagian. Wilayah 1 sekitar pintu masuk, kolam air panas 1, dan batu menangis. Wilayah 2 sekitar kolam air panas 2. Wilayah 3 sekitar kolam renang utama dan Wilayah 4 sekitar air terjun.

Adapun instrument pengumpulan data yang digunakan pada penelitian ini, yaitu: Lembar pedoman wawancara, lembar observasi lapangan dan lembar perbandingan morfologi, lembar angket validasi ahli materi, ahli bahan ajar, guru biologi, dan lembar angket respon siswa serta rubrik penilaian. Alat dan bahan yang digunakan dalam penelitian ini yaitu : alat (Plastik, tali plastik, cutter/pisau, gunting, jarum, benang, lem kertas, kertas koran, penggaris, label spesimen, karton, kertas A4, pena, spidol, karton padi, kamera), bahan (Tanaman Paku, Alkohol $70 \%$, Silabus dan RPP SMA, Buku Catatan Lapangan, Buku IPA SMA Kelas X).

Untuk mengetahui kevalidan dari booklet yang telah dikembangkan, digunakan lembar angket validasi yang akan diisi oleh ahli materi, bahan ajar dan guru biologi. Skor yang didapat dihitung menggunakan rumus :

$$
\begin{aligned}
\mathrm{P}=\frac{\sum \mathrm{x}}{\sum \mathrm{xi}} \mathrm{x} 100 \% \\
\text { (Rif'atus sulcha, 2013). }
\end{aligned}
$$

Keterangan:

$\mathrm{P} \quad=$ Persentase Kevalidan

$\Sigma X i=$ jumlah nilai ideal peritem

$\Sigma \mathrm{X}=$ jumlah skor jawaban responden

$100 \%=$ konstanta

Hasil analisis data yang berupa persentase tersebut kemudian dicocokkan dengan kriteria kevalidan yang dapat dilihat pada Tabel 1.

Tabel 1. Kriteria Kevalidan Data Hasil Penilaian

\begin{tabular}{|l|l|l|}
\hline Tingkat Persentase & Kriteria & Keterangan \\
\hline $81,25 \%-100 \%$ & $\begin{array}{l}\text { Sangat } \\
\text { Valid }\end{array}$ & $\begin{array}{l}\text { Layak/ } \\
\text { tidak revisi }\end{array}$ \\
\hline $62,50 \%-81,24 \%$ & Valid & $\begin{array}{l}\text { Cukup } \\
\text { Layak/ } \\
\text { tidak revisi }\end{array}$ \\
\hline $43,75 \%-62,49 \%$ & $\begin{array}{l}\text { Kurang } \\
\text { valid }\end{array}$ & $\begin{array}{l}\text { Kurang } \\
\text { layak/ } \\
\text { revisi } \\
\text { sebagian }\end{array}$ \\
\hline $25 \%-43,74 \%$ & $\begin{array}{l}\text { Sangat } \\
\text { kurang }\end{array}$ & $\begin{array}{l}\text { layak/ } \\
\text { layak }\end{array}$ \\
\hline
\end{tabular}




\begin{tabular}{|l|l|l|}
\hline & valid & revisi total \\
\hline
\end{tabular}

Nilai yang diperoleh kemudian diinterpretasi berdasarkan kriteria kevalidan data hasil penilaian. Setiap kriteria dinyatakan layak jika mencapai tingkat persentase $62,50 \%-81,24 \%$. Seperti yang tercantum pada tabel 3.1. Kemudian terkait komentar dan saran perbaikan untuk penyempurnaan booklet, akan di perbaiki sebelum diuji cobakan pada siswa.

Data yang diperoleh dari angket respon siswa akan dianalisis secara klasikal dengan menggunakan rumus

$$
\mathrm{P}=\frac{f}{N} \times 100 \%
$$

Sugiyono (2009) dalam Sugianto

\section{Keterangan :}

$\mathrm{P}=$ angka presentase respon siswa

$f=$ banyaknya skor yang diperoleh

$\mathrm{N}=$ jumlah skor maksimal

Hasil analisis data yang berupa persentase tersebut kemudian dicocokkan dengan tabel kriteria respon siswa yang dapat dilihat pada Tabel 2 .

Tabel. 2. Kriteria Respon Siswa

\begin{tabular}{|c|c|}
\hline Skor & Kriteria \\
\hline $76 \%-100 \%$ & Sangat baik \\
\hline $51 \%-75 \%$ & Baik \\
\hline $26 \%-50 \%$ & Cukup baik \\
\hline$\leq 25 \%$ & Tidak baik \\
\hline
\end{tabular}

\section{HASIL DAN PEMBAHASAN}

Berdasarkan hasil penelitian keanekaragaman jenis tumbuhan paku yang ada dikawasan objek wisata Suban Air Panas Kabupaten Rejang Lebong yang telah dilakukan, ditemukan 7 family, 12 genus dan 14 spesies seperti yang tertera pada Tabel 3.

Tabel.3. keanekaragaman tumbuhan paku yang ditemukan

\begin{tabular}{|c|c|c|}
\hline Family & Genus & Spesies \\
\hline \multirow{6}{*}{ Polypodiaceae } & \multirow{2}{*}{ Pyrrosia } & $\begin{array}{c}\text { Pyrrosia } \\
\text { angustata }\end{array}$ \\
\hline & & $\begin{array}{l}\text { Pyrrosia } \\
\text { rasamala }\end{array}$ \\
\hline & Drymoglossum & $\begin{array}{c}\text { Drymoglosum } \\
\text { piloselloides }\end{array}$ \\
\hline & Drynaria & Drynaria $s p$ \\
\hline & Asplenium & $\begin{array}{c}\text { Asplenium } \\
\text { nidus }\end{array}$ \\
\hline & Cyclosorus & Cyclosorus sp \\
\hline \multirow{2}{*}{ Dryopteridaceae } & \multirow{2}{*}{ Nephrolepis } & $\begin{array}{c}\text { Nephrolepis } \\
\text { biserrata }\end{array}$ \\
\hline & & $\begin{array}{c}\text { Nephrolepis } \\
\text { hirsutula }\end{array}$ \\
\hline Adiantaceae & Adiantum & Adiantum sp \\
\hline Selaginellaceae & Selaginella & Selaginella $s p$ \\
\hline Polypodiaceae & Davallia & $\begin{array}{c}\text { Davallia } \\
\text { denticulate }\end{array}$ \\
\hline Equisetaceae & Equisetum & $\begin{array}{c}\text { Equisetum } \\
\text { debile }\end{array}$ \\
\hline Pteridaceae & Pteris & Pteris vittata \\
\hline Marattiaceae & Angiopteris & $\begin{array}{c}\text { Angiopteris } \\
\text { avecta }\end{array}$ \\
\hline
\end{tabular}

Dari 14 jenis spesies yang ditemukan Di Kawasan Objek Wisata Suban Air Panas bahwa paku dari family Polypodiaceae merupakan family yang paling banyak ditemui jenisnya. Yaitu 7 jenis : Pyrrosia angustata, Pyrrosia rasamala, Drymoglosum piloselloides, Drynaria $s p$, Asplenium nidum, Cyclosorus sp dan Davallia denticulate. Dari ke empat wilayah lokasi pengamatan yang telah ditentukan memiliki jenis yang berbedabeda. Wilayah yang paling banyak ditemukan tumbuhan paku yaitu wilayah pengamatan 2 yaitu wilayah sekitar kolam renang air panas 2 sebanyak 12 spesies. 
Sedangkan wilayah dengan jumlah paling sedikit ditemukan pada wilayah 3 yaitu kolam renang utama yang hanya ditemukan 1 spesies tumbuhan paku.

Wilayah 1 adalah wilayah sekitar area pintu masuk, batu menangis dan kolam renang air panas 1 . Jumlah yang ditemukan pada wilayah ini adalah 5 jenis yaitu Pyrrosia angustata, Drymoglosum piloselloides, Drynaria sp, Cyclosorus sp dan Davallia denticulate. Dari ke 5 jenis ini merupakan paku epifit pada pohon dengan batang besar bahkan ada yang berada pada atap pondok. Selain itu ke 5 jenis ini mendapatkan intensitas cahaya yang cukup. Dari ke 5 jenis tersebut 2 diantaranya hidup berdampingan pada atap pondok yaitu Pyrrosia angustata dan Drynaria sp. Sejalan dengan hasil penelitian Nahu,dkk (2013) menyatakan bahwa jenis-jenis tumbuhan paku epifit yang mendominasi pada pohon karena menyukai cahaya matahari yang cukup, dengan keadaan temperatur yang sesuai.

Wilayah 2 yaitu Kolam air panas 2, pada wilayah ini ditemukan sebanyak 12 spesies yaitu Pyrrosia angustata, Pyrrosia rasamala, Drymoglosum piloselloides, Asplenium nidum, Cyclosorus sp, Nephrolepis biserrata, Nephrolepis hirsutula, Selaginella sp, Davallia denticulate, Equisetum debile, Pteris vittata dan Angiopteris avecta. Dari 12 jenis yang ditemukan hampir sebagiannya merupakan paku epifit, hal ini dikarenakan pada wilayah 2 lokasi banyak ditumbuhi oleh pohon besar, dekat dengan sungai, ketika pagi hari dan sore hari wilayah ini ditutupi embun (Kabut). Hal ini sejalan dengan penelitian Hariyadi (2000), bahwa kelembapan udara dari kabut lebih menguntungkan untuk tumbuhan paku epifit dibandingkan dengan tetesan air hujan langsung.

Wilayah 3 yaitu kolam renang utama. Pada lokasi ini hanya ditemukan 1 jenis tumbuhan paku, yaitu Drymoglosum piloselloides. Hal ini dikarenakan lokasi kolam renang utama yang tidak memungkinkan untuk ditumbuhi tumbuhan paku, Tidak ditemukannya pohon besar untuk paku epifit dapat tumbuh dan wilayah ini paling ramai dikunjui oleh pengunjung Objek Wisata Suban Air Panas Kabupaten Rejang Lebong.

Wilayah 4 yaitu sekitar air terjun. Pada wilayah ini ditemukan 4 jenis tumbuhan paku, yaitu Cyclosorus $s p$, Adiantum sp, Selaginella sp dan Davallia denticulate. Dari ke 4 jenis paku yang ditemukan bahwa batu dapat tumbuh di pingiran air terjun atau diantara bebatuan. Selain itu diantara ketiga wilayah sebelumnya lokasi ini memiliki suhu udara, suhu tanah, dan kelembapan udara yang lebih rendah dibandingkan dengan yang lainnya. Hal ini sejalan dengan penelitian Sandy, dkk (2016) menyatakan bahwa keanekaragaman jenis tumbuhan paku secara tidak langsung dipengaruhi oleh faktor abiotik, seperti suhu udara, kelembapan, suhu tanah, intensitas cahaya dan ketinggian tempat.

Pada tahap pengembangannya, booklet sebelum digunakan dalam pembelajaran, terlebih dahulu divalidasi oleh 3 orang validator, 2 dosen FKIP UniversitaS Bengkulu dan 1 Guru Biologi SMA. Berdasarkan hasil analisis data angket validasi diperoleh rata-rata tingkat kevalidan booklet dari ke-3 validator mencapai $92 \%$ berdasarkan hasil validasi tersebut dapat diketegorikan sangat valid dengan keterangan layak digunakan tanpa harus direvisi. Hasil analisis angket validasi dapat dilihat pada Tabel 4.

Tabel 4. Hasil Analisis Data Angket Validasi LKS

\begin{tabular}{|c|c|c|c|}
\hline Validator & $\begin{array}{c}\text { Perbaikan dan } \\
\text { saran perbaikan }\end{array}$ & $\%$ & Kriteria \\
\hline $\begin{array}{c}\text { Validator } \\
1\end{array}$ & $\begin{array}{l}\text { - Penggunaan } \\
\text { warna Cover } \\
\text { booklet harus } \\
\text { terang, judul }\end{array}$ & $91 \%$ & $\begin{array}{c}\text { Sangat } \\
\text { Valid }\end{array}$ \\
\hline
\end{tabular}




\begin{tabular}{|c|c|c|c|}
\hline & $\begin{array}{l}\text { harus lebih } \\
\text { dipertegas } \\
\text { dan warna } \\
\text { background } \\
\text { cover tidak } \\
\text { boleh lebih } \\
\text { terang dari } \\
\text { judul. } \\
\text { Ditambahkan } \\
\text { soal latihan } \\
\text { Materi } \\
\text { ditambahkan } \\
\text { lebih banyak } \\
\text { lagi }\end{array}$ & & \\
\hline $\begin{array}{c}\text { Validator } \\
2\end{array}$ & 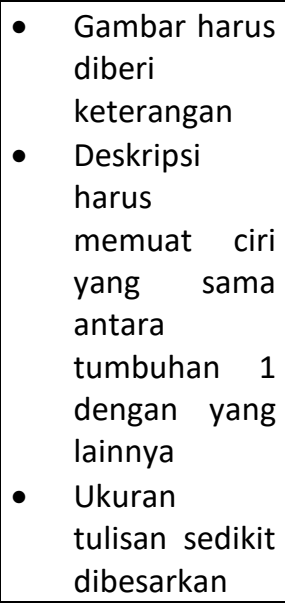 & $90 \%$ & $\begin{array}{c}\text { Sangat } \\
\text { Valid }\end{array}$ \\
\hline $\begin{array}{c}\text { Validator } \\
3\end{array}$ & 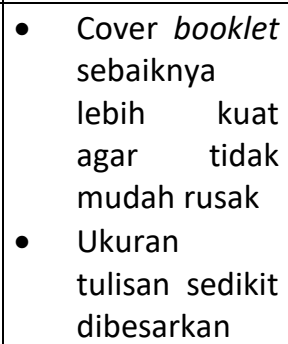 & $94 \%$ & $\begin{array}{c}\text { Sangat } \\
\text { Valid }\end{array}$ \\
\hline \multicolumn{2}{|r|}{ Rata-rata } & $92 \%$ & $\begin{array}{c}\text { Sangat } \\
\text { Valid }\end{array}$ \\
\hline
\end{tabular}

Untuk mengetahui keefektifan booklet yang dikembangkan sebagai bahan ajar juga dilihat dari respon siswa terhadap booklet yang dikembangkan dengan menggunakan lembar respon siswa. Angket respon siswa berisikan 10 butir indikator. Kelas yang di uji cobakan adalah kelas X IPA 5 SMA Negeri 1 Rejang Lebong sebanyak 33 orang siswa. Hasil angket respon siswa terhadap booklet yang telah diperoleh dengan presentase $83 \%$ dengat kategori sangat baik. Hasil analisis data angket respon siswa dapat dilihat pada Tabel 5. Hal ini sesuai dengan tabel kriteria respon siswa bahwa kriteria yang sangat baik jika skornya mencapai $76 \%$ - $100 \%$.

Tabel 5. Hasil Analisis Data Angket Respon Siswa

\begin{tabular}{|c|c|c|c|}
\hline \multirow{2}{*}{ No } & \multirow{2}{*}{ Indikator } & \multicolumn{2}{|c|}{ Skor } \\
\hline & & $\Sigma$ & (\%) \\
\hline 1. & $\begin{array}{l}\text { Tampilan booklet } \\
\text { kreatif dan menarik } \\
\text { perhatian }\end{array}$ & 99 & $75 \%$ \\
\hline 2. & $\begin{array}{l}\text { Penyusunan runtun } \\
\text { dan terstruktur } \\
\text { dengan baik }\end{array}$ & 120 & $91 \%$ \\
\hline 3. & $\begin{array}{l}\text { Ketepatan dalam } \\
\text { penyajian ilustrasi, } \\
\text { tabel, dan foto }\end{array}$ & 108 & $82 \%$ \\
\hline 4. & $\begin{array}{l}\text { Kalimat mudah } \\
\text { dibaca }\end{array}$ & 116 & $88 \%$ \\
\hline 5. & $\begin{array}{l}\text { Bahasa mendukung } \\
\text { kemudahan } \\
\text { pemahaman alur } \\
\text { materi }\end{array}$ & 120 & $91 \%$ \\
\hline 6. & $\begin{array}{l}\text { Penggunaan bahasa } \\
\text { sesuai EYD }\end{array}$ & 102 & $77 \%$ \\
\hline 7. & $\begin{array}{l}\text { Ketertautan antara } \\
\text { alinea atau kalimat }\end{array}$ & 106 & $80 \%$ \\
\hline 8. & $\begin{array}{l}\text { Siswa dapat lebih } \\
\text { memahami } \\
\text { pembelajaran } \\
\text { Pteridophyta dengan } \\
\text { menggunakan } \\
\text { booklet }\end{array}$ & 113 & $86 \%$ \\
\hline 9. & $\begin{array}{l}\text { Menumbuhkan } \\
\text { minat belajar }\end{array}$ & 111 & $84 \%$ \\
\hline 10. & $\begin{array}{l}\text { Mendorong untuk } \\
\text { mencari informasi } \\
\text { lebih lanjut }\end{array}$ & 101 & $76 \%$ \\
\hline & Jumlah & 1096 & $83 \%$ \\
\hline
\end{tabular}

Keterangan:

- Jumlah siswa yang memberikan respon adalah 33 siswa.

- Skor Maksimal (N) adalah 4 x $33=132$

Booklet yang dikembangkan dibuat dalam 53 halaman. Booklet memuat beberapa aspek seperti Judul besar, Kata Pengantar, Deskripsi Suban Air Panas, Daftar Isi, Materi Tumbuhan Paku, Kunci 
Determinasi, Latihan Soal, Daftar Pustaka dan Biografi Penulis. Materi yang disajikan sesuai dengan KI dan KD 3.8 kelas X SMA Kurikulum 2013. Materi dijabarkan dalam booklet berkaitan dengan pengertian tumbuhan paku, ciri-ciri umum, klasifikasi tumbuhan paku, siklus hidup tumbuhan paku, metagenesis tumbuhan paku, serta manfaat tumbuhan paku bagi kehidupan.

\section{PENUTUP}

\section{Simpulan}

1. berdasarkan hasil identifikasi tumbuhan paku (Pteridophyta) Di Kawasan Objek Wisata Suban Air Panas Kabupaten Rejang Lebong ditemukan 14 jenis spesies yaitu Pyrro, sia angustata, Pyrrosia rasamala Drymoglosum piloselloides, Drynaria sp, Asplenium nidus, Cyclosorus sp, Nephrolepis biserrata, Nephrolepis hirsutula, Adiantum sp, Selaginellasp, Davallia denticulate, Equisetum debile, Pteris vittata dan Angiopteris avecta.

2. Booklet yang dikembangkan berdasarkan identifikasi tumbuhan paku (Pteridophyta) dikawasan Objek Wisata Suban Air Panas Kabupaten Rejang Lebong, dapat dijadikan sebagai salah satu bahan ajar yang dapat digunakan untuk proses pembelajaran Biologi bagi siswa SMA N 1 Rejang Lebong kelas X. Skor akhir validasi yang diperoleh menurut 3 validator adalah $92 \%$ dengan kriteria sangat baik. Skor akhir untuk angket respon siswa yaitu $83 \%$ dengan kriteria sangat baik.

\section{SARAN}

1. Guru dapat mencoba membuat bahan ajar yang dirancang sendiri untuk digunakan saat proses pembelajaraan baik di dalam kelas ataupun di lapangan.
2. Saat pengambilan sampel tumbuhan paku hendaknya menggunakan beberapa alat keselamatan untuk mendukung proses pengambilan.

3. Pada kegiatan uji coba booklet, hendaknya proses pengamatan dapat dilakukan langsung di kawasan wisata Suban Air Panas sehingga siswa dapat menemukan sendiri jenis tumbuhan paku yang ditemuinya, dengan mengamati ciri morfologi secara langsung serta mampu meberikan nama jenis tumbuhan paku yang ditemukan berdasarkan booklet yang dikembangkan.

\section{DAFTAR PUSTAKA}

Arifin, Zainal. 2011. Penelitian Pendidikan (metode dan paradifma baru). Bandung : Rosda.

Hariyadi, Bambang. 2000. Sebaran keanekaragaman jenis tumbuhan paku di bukit sari, jambi. Bogor: IPB.

Imtihana, Mutia. F. Putut Martin, H.B. \& Bambang Priyono. 2014. Pengembangan Buklet Berbasis Penelitian Sebagai Sumber Belajar Materi Pencemaran Lingkingan Di SMA. Unnes Journal of Biology Education. 3 (2) : 186-192.

Izmuka. 2015. Obyek wisata dibengkulu suban air panas. http://www.infokita.com/obyek-wisata-dibengkulu-suban-air-panas/ (diakses 20 januari 2017).

Majid, abdul. 2009. Perencanaan Pembelajaran. Mengembangkan Standar Kompetensi Guru.

Nahu, Titi D. Wirnangsi, U. dan Abubakar, S. 2013. Keanekaragaman Dan BioEkologis Tumbuhan Paku (Pteridophyta) Di Kawasan Cagar Alam Gunung Ambang Sub Kawasan Kabupaten Bolaang Mongondow Timur. Gorontalo.

Pralisaputri, K. Heribertus, S. dan Chatarina, M. 2016. Pengembangan Media Booklet Berbasis Sets Pada Materi Pokok Mitigasi Dan Adaptasi Bencana 
Alam Untuk Kelas X SMA. GeoEco. 2

(2) : 147-154.

Prastowo, Adi. 2011. Panduan Kreatif membuat bahan Ajar Inovatif. Jogjakarta : DIVA Press.

Pusat Data dan Informasi. 2016. Statistik Kementrian Lingkungan Hidup dan Kehutanan Tahun 2015. Jakarta: Kementrian Lingkungan Hidup Dan Kehutanan.

Rencana Pembangunan Jangka Menengah Daerah (RPJMD). 2014. Gambaran Umum Kondisi Daerah. HIm.11-14.

Sandy, S Fari. Yuni, P. dan Atok M. 2016. Keanekaragaman Jenis Tumbuhan Paku (Pteridophyta) Di Kawasan Air Terjun Lawean Sendang Kabupaten Tulung Agung. Malang : Prosiding Seminar Nasional.

Soesilo, dkk. 1986. Buku Materi Pokok Biologi. Jakarta: Universitas Terbuka press.

Sugianto. 2013 . Pengembangan LKS Berbasis Keterampilan Proses Pada Tema Fotosintesis Untuk Meningkatkan Kemampuan Kerja Ilmiah. Universitas Negeri Semarang.

Sugiyono. 2008. Metode Penelitian Pendidikan (Pendekatan Kuantitatif, Kualitatif dan R \& D). Bandung : Alfabeta.

Suyitno, Imam. 2011. Cara Mudah Dalam Perencanaan Penelitian Tindakan Kelas (PTK). Bandung : PT. Rafika Aditama.

Tjitrosoepomo, Gembong. 1994. Taksonomi tumbuhan. Yogyakarta: UGM Press. 